\title{
PREFERENSI PERMODALAN PEDAGANG PASAR WAGE PURWOKERTO, PENGUATAN DESTINASI KEUANGAN DAN PERBANKAN SYARIAH VIS A VIS RENTENIR DI PASAR TRADISIONAL
}

\author{
Dewi Laela Hilyatin \\ Institut Agama Islam Negeri Purwokerto \\ dewilaelahilyatin@gmail.com
}

\begin{abstract}
Abstrak
Dalam mengembangkan usaha salah satu instrumen pokoknya adalah modal. Ketercukupan modal dapat menjadikan muara masalah bagi pelaku usaha termasuk di dalamnya pedagang pasar tradisional. Banyaknya sumber permodalan di kalangan masyarakat menyebabkan pedagang harus membuat preferensi dalam menentukan sumber permodalan yang tepat. Diantara sumber permodalan yang masih berkembang di kalangan masyarakat khususnya pedagang pasar wage adalah rentenir. Rentenir masih menjadi alternative pilihan pedagang pasar wage dengan jumlah $11 \%$, karena beberapa hal diantaranya: kemudahan dalam proses peminjaman, tanpa syarat, tidak terbatas ruang dan waktu. Tetapi kemudahan itupun tidak terlepas dari permasalahan yang bermunculan. Oleh karena itu pemerintah dalam hal ini OJK melakukan beberapa upaya dalam melindungi masyarakat dari rentenir melalui majalah edukasi OJK, pamflet, banner, dan sosialisasi langsung kepada masyarakat. Untuk penguatan destinasi Lembaga keuangan bank atau non bank perlu dilakukan 8 strategi dan 1 monev yang diadopsi dari strategi penguatan destinasi wisata oleh BI, OJK, pemerintah daerah.
\end{abstract}

Kata Kunci: preferensi, permodalan pedagang, destinasi keuangan, Lembaga keuangan

\begin{abstract}
In developing a business, one of the main instruments is capital. Adequacy of capital can create a problem for business actors including traditional market traders. The many sources of capital in the community cause traders to make preferences in determining the right source of capital.
\end{abstract}


Among the capital sources that are still developing among the community, especially the Wage market traders, are moneylenders. Moneylenders are still an alternative choice for wage market traders with an amount of $11 \%$, because of several things including: ease in the loan process, without conditions, unlimited space and time. But even that convenience is inseparable from the problems that have arisen. Therefore, the government, in this case the OJK, has made several efforts to protect the public from loan sharks through the OJK education magazine, pamphlets, banners, and direct socialization to the public. To strengthen the destination of banks or non-bank financial institutions, 8 strategies and 1 monitoring and evaluation need to be adopted from the strategy of strengthening tourist destinations by BI, OJK, local governments.

Keywords: preferences, capital of traders, financial destinations, financial institutions

\section{A. Latar Belakang Masalah}

Modal kerja merupakan instrumen pokok yang dibutuhkan bagi ketersedianya volume barang yang dibutuhkan oleh konsumen (masyarakat). Modal kerja yang dimaksud merupakan sumber pembiayaan siklus operasional sehari-hari, baik yang bersifat konsumtif maupun produktif. Bagi kalangan pedagang tradisional, yang notabenenya adalah pedagang kecil, mereka pada umumnya kurang memiliki perhatian yang serius di dalam pencarian dan pengelolaan sumber dana modal kerja. Hal ini kerap sekali memaksa para pedagang tradisional dihadapkan dengan situasi dimana mereka kehabisan modal kerja. Perhatian serius terhadap modal kerja bagi para pedagang diyakini akan berpengaruh signifikan bagi peningkatan usaha perdagangan yang ditandai dengan naiknya tingkat pendapatan.

Diskursus terkait ketercukupan modal kerja (adequacy capital) di kalangan pedagang tradisional merupakan hulu permasalahan keuangan yang berpotensi menimbulkan berbagai problematika serius bagi stabilitas persediaan komoditas pasar. Kelangkaan modal kerja akan menimbulkan efek domino yang tidak hanya berdampak langsung kepada pedagang, namun juga akan berpengaruh bagi daya beli masyarakat (inflasi) dan income pemerintah (pajak dan retribusi pasar). Permodalan sebagai parameter penetapan tingkat harga eceran di pasaran pada kelanjutannya menduduki posisi strategis di dalam stabilitas suatu pasar. 
Selama ini modal usaha dipahami sebagai uang yang digunakan untuk pokok (induk) berdagang, melepas uang, dan sebagainya; harta benda (uang, barang, dan sebagainya yang dapat dipergunakan untuk menghasilkan sesuatu yang menambah kekayaan ${ }^{1}$. Sumber modal antara lain: modal sendiri, yang merupakan modal yang diperoleh dari si pemilik usaha tersebut, berasal dari tabungan, investasi bersama, hibah, dan lain sebagainya. Modal pinjaman yang berasal dari pinjaman perbankan atau lembaga keuangan lainnya seperti koperasi. Sedangkan modal lainnya berasal dari sumber keuangan 'abu-abu' seperti lembaga keuangan tidak resmi semacam rentenir, lintah darat dan peretas uang berkedok koperasi simpan pinjam $(\mathrm{KSP})^{2}$.

Pedagang-pedagang dalam menentukan pilihan sumber permodalannya akan memiliki berbagai pertimbangan dan alasan sehingga pilihan sumber permodalannya dapat memberikan manfaat bagi pedagang tersebut. Pedagang pada umumnya dalam menentukan preferensinya disesuaikan dengan kemampuan dan kesesuaian penggunaannya. Selain itu, pedagang juga mayoritas menentukan pilihan sumber permodalannya melihat dari prosedur pengajuan dan pembayaran pinjaman yang mudah. Dalam menjalankan kegiatan perdagangannya para pedagang menggunakan bermacam-macam sumber permodalan. Sumber permodalan tersebut di antaranya ada yang menggunakan modal sendiri, modal dari Baitul Maal wat Tamwil, modal dari rentenir, dan pernah meminjam di bank namun sudah tidak meminjam lagi ${ }^{3}$. Hal tersebut disebabkan karena pedagang tidak mau terbebani dengan lembaga keuangan yang menetapkan persyaratan dan prosedur yang rumit.

Pasar wage Purwokerto sebagai pasar induk terbesar di wilayah kabupaten Banyumas, dengan jumlah pedagang lebih dari 1500 orang. Tahun 2019 Dinperindagkop Kabupaten Banyumas mencanangkan pasar wage sebagai pasar destinasi wisata seperti Pasar Bringharjo di Jl. Malioboro Yogyakarta. Dengan jumlah pedagang yang cukup besar tentunya memiliki potensi pengembangan yang bisa dimaksimalkan menjadi destinasi wisata. Namun demikian permasalahan yang terjadi terkait Pasar Wage cukup kompleks. Mulai dari sengketa kios, tatanan

1 Kamus Besar Bahasa Indonesia; http://kbbi.web.id/modal (diakses pada senin 18 Sepetember 2017)

2 Toti Indrawati dan Indri Yovita, Analisis Sumber Modal Pedagang Pasar Tradisional di Kota Pekanbaru, Jurnal Ekonomi, Vol. XXII, (Pekanbaru; Universitas Riau, 2014).

3 Mar'atus Syawalia Navis, Preferensi Pedagang Pasar Tradisional terhadap Sumber Permodalan, Jurnal Ekonomi Dan Bisnis (Malang; Universitas Brawijaya, 2015) 
pasar yang "semrawut", kumuh, manajemen yang kurang baik dan tentunya masalah yang belum disentuh oleh para peneliti adalah preferensi permodalan pedagang. Lebih dari $10 \%$ pedagang terlibat dengan rentenir "koperasi abal abal", padahal jumlah lembaga keuangan resmi yang dilindungi pemerintah baik konvensional maupun syariah suduh cukup banyak di wilayah purwokerto.

Merujuk pada premis diskursus di atas, penulis tertarik untuk mambahas lebih lanjut terkait pergumulan preferensi permodalan pedagang-rentenir di pasar tradisional; penguantan destinasi lembaga keuangan, perbankan syariah vs rentenir. Pembacaan ulang atas obyek konsep-konsep ekonomi dan bisnis ini menjadi sangat penting. Hal ini mengingat semakin rendahnya animo kalangan menengah ke bawah guna memanfaatkan jasa-jasa lembaga keuangan syariah yang konsep dan pergerakan teorinya menjadi fokus pembahasan dalam bidang Ekonomi Islam.

\section{B. Preferensi Permodalan Pedagang \\ 1. Definisi dan Jenis Prefesensi}

Di dalam kamus besar bahasa Indonesia kata preferensi memiliki beberapa arti yaitu (hak untuk) didahulukan dan diutamakan daripada yang lain; prioritas; pilihan; kecenderungan; kesukaan ${ }^{4}$. Menurut Kotler preferensi konsumen menunjukkan kesukaan konsumen dari berbagai pilihan produk jasa yang $\mathrm{ada}^{5}$. Preferensi juga diartikan sebagai pilihan suka atau tidak suka oleh seseorang terhadap suatu produk, barang atau jasa yang dikonsumsi.

Sedangkan menurut Andi Mappiare definisi preferensi adalah suatu perangkat mental yang terdiri dari suatu campuran dari perasaan, harapan, pendirian, prasangka, rasa takut atau kecenderungan lain yang mengarahkan individu kepada suatu pilihan tertentu. ${ }^{6}$

Pelanggan dalam memutuskan untuk melakukan transaksi memiliki karakteristik yang berbeda beda. Penjual tidak dapat mengendalikan karakteristik-karakteristik pembeli, mereka hanya memperhitungkan implementasi dari masing-masing karakteristik tersebut.Karakteristik preferensi pelanggan dalam menentukan pilihan memiliki tiga prinsip

4 https://kbbi.web.id, diakses pada 8 Agustus 2018

5 Philip Kotler, Manajemen Pemasaran, Prehalindo, Jakarta, Cet Ke-10, 2000, h. 154 
pilihan rasional yaitu: ${ }^{7}$ Kelengkapan (Completeness), Transivitas (Transivity) dan Kontinuitas (Continuity). Menurut Nugroho J. Setiadi, preferensi terhadap barang dan jasa dipengaruhi oleh empat faktor, yaitu ${ }^{8}$ : kebudayaan, sosial, pribadi, dan psikologis.

Preferensi dalam Islam dikaji cara penggunaan yang harus diarahkan pada pilihan yang mengandung maslahah. Agar kekayaan atau harta tersebut dapat memberikan manfaat untuk kesejahteraan bagi individu tersebut $^{9}$. Preferensi memiliki arti pilihan atau kecenderungan (kebebasan) individu dalam memilih. Kebaikan yang paling utama ialah kebebasan individu untuk memilih suatu alternatif yang tepat walaupun peluang untuk memilih alternatif lain yang salah juga besar. Kebebasan individu, bukannya mutlak dan tanpa batasan, melainkan dibatasi oleh dua hal: pertama: individu bebas bergerak dengan syarat tidak melanggar dan mengambil hak-hak orang lain ,kedua: dia harus mengambil cara yang halal untuk mencari penghidupan dan tidak mengambil benda-benda yang haram.

Seorang mukmin hendaknya senantiasa menggunakan hak dan kebabasan mereka berdasarkan prinsip yang telah digariskan. Batasanbatasan disusun menurut konsep perkara baik (thaibat) dan perkara buruk (khaibaith), yang memberi kebebasan kepada umat Islam untuk memperoleh dan memiliki sesuatu menurut cara mereka. Islam melarang semua cara tidak benar yang kerap dilakukan manusia untuk mendapatkan hak orang lain, tidak adil, buruk dan keji ${ }^{10}$.

\section{Permodalan Pedagang}

Menurut Prof. Thomas, modal adalah milik individu dan negara yang digunakan dalam menghasilkan aset berikutnya selain tanah. Modal dapat

6 Andi Mappiare, Psikologi Orang Dewasa Bagi Penyesuaian Dan Pendidikan, Surabaya, Usana Offsetprinting, 1994, hlm . 62

7 Nur Rianto Al Arif, Teori Mikroekonomi, Kencana, Jakarta, 2010, hlm. 110

8 Nugroho, J. Setiadi, Perilaku Konsumen, Jakarta: Kencana Prenada Meida Group, 2013, hlm. 10

9 Mar'atus Syawalia, Preferensi Pedagang Pasar Tradisional Terhadap Sumber Modal, Jurnal Ilmiah, 2015, hlm. 4. 40 Nur Rianto Al Arif, Teori Mikroekonomi, Kencana, Jakarta, 2014, hlm. 93

${ }^{10}$ Afzalur Rahman, Doktrin Ekonomi Islam, Dana Bhakti Wakaf, Yogyakarta, 1995, hlm. 94

\section{el-JIZYA}


memberikan kepuasan pribadi dan membantu untuk menghasilkan kekayaan lebih banyak ${ }^{11}$. Ahmad Ibrahim mendefinisikan modal sebagai kekayaan yang menghasilkan hasil yang akan digunakan untuk menghasilkan kekayaan lain. ${ }^{12}$

Pada dasarnya, kebutuhan modal untuk melakukan usaha terdiri dari dua jenis yaitu modal investasi dan modal kerja ${ }^{13}$. Modal investasi digunakan untuk jangka panjang (lebih dari 1 tahun) dan dapat digunakan berulang-ulang. Sementara modal kerja digunakan jangka pendek (kurang dari 1 tahun) dan beberapa kali pakai dalam satu proses produksi.

Modal investasi jangka panjang merupakam porsi terbesar dalam komponen pembiayaan suatu usaha dan biasanya dikeluarkan pada awal perusahaan didirikan atau untuk perluasan pabrik dan digunakan untuk membeli aktiva tetap Modal investasi biasanya diperoleh dari modal pinjaman yang diperoleh dari perbankan.

Setelah kebutuhan modal investasi terpenuhi, selanjutnya adalah pemenuhan kebutuhan modal kerja. Modal kerja, yaitu modal yang digunakan untuk membiayai operasional perusahaan pada saat perusahaan sedang beroperasi. Jenis modalnya bersifat jangka pendek, biasanya hanya digunakan untuk sekali atau beberapa kali proses produksi.

Beberapa pertimbangan yang perlu diperhatikan apabila ingin memperoleh suatu modal adalah ${ }^{14}$ : Tujuan perusahaan, masa pengembalian modal, biaya yang dikeluarkan dan estimasi keuntungan Kebutuhan modal diperoleh dari berbagai sumber dana yaitu: Modal sendiri, Modal Asing (Pinjaman) dan Modal Campuran

Modal dalam literatur Fiqh disebut " $R a$ 'sul Maal” menunjukkan pada pengertian uang dan barang. Berdasarkan pengertian modal dalam literatur Fiqh dan penguraiannya dalam sistem ekonomi Islam, maka pembahasan modal sebagai faktor produksi dapat dibagi dalam dua pembahasan ${ }^{15}$ : Pertama, alat produksi, Islam memperlakukan alat-alat yang digunakan untuk memproduksi barang dan jasa seperti mesin tekstil, traktor pertanian, sama dengan hukum sewa menyewa sebagaimana ditulis dalam kitab-kitab fiqh. Kedua, uang dan barang, berbeda dengan alat-alat

${ }^{11}$ Ibid, hlm. 285

${ }^{12}$ Rustam Effendi, Produksi dalam Islam, Magistra Insani Press Bekerjasama dengan MSI UII, Yogyakarta, 2003, h. 61. 47 Kasmir, Kewirausahaan, Rajawali Pers, Jakarta, 2013, hlm. 98.

${ }^{13}$ Kasmir, Kewirausahaan, Edisi Revisi, (Jakarta: Rajagrafindo Persada, 2011), hlm. 91

${ }^{14} \mathrm{Ibid}$, hlm. 94.

15 Rustam Efendi, Produksi Dalam Islam, Magister Press Bekerjasama dengan MSI UII, Yogyakarta, 2003, h. 63-64 43 
produksi, modal uang dan barang diposisikan sebagai pihak yang menerima bagian dari keuntungan apabila modal tersebut dikelola orang lain dan pemilik modal juga menanggug risiko kerugian yang ditimbulkan akibat kerja ekonomi antara pemilik modal dan pengelola.

Adapun bentuk-bentuk pengembangan modal menurut ketentuan syari'ah muamalah, dapat dilakukan dalam bentuk dan pola pembiayaan ${ }^{16}$ : pembiayaan bagi hasil (akad mudharabah atau musyarakah), pembiayaan pola jual beli (akad murabahah, salam atau istishna').

\section{Penguatan Destinasi Lembaga Keuangan di wilayah KOJK Purwokerto}

Lembaga keuangan adalah perusahaan yang bergerak di bidang keuangan, menghimpun dan atau menyalurkan dana. Dalam praktiknya lembaga keuangan digolongkan menjadi dua yaitu: lembaga keuangan bank (bank central, bank umum dan bank perkreditan rakyat) dan lembaga keuangan lainnya. ${ }^{17}$ Sedangkan lembaga keuangan non bank diantaranya ${ }^{18}$ : pasar modal, pasar uang dan valas, koperasi simpan pinjam, pegadaian, perusahaan sewa guna usaha, perusahaan asuransi, perusahaan anjak piutang, Modal ventura, dan dana pensiun.

Bank adalah lembaga intermediasi keuangan yang didirikan dengan kewenangan untuk menerima simpanan uang, meminjamkan uang, dan menerbitkan promes atau yang dikenal sebagai banknote. Menurut undang-undang bank adalah badan usaha yang menghimpun dan menyalurkan dana dalam rangka meningkatkan taraf hidup rakyat banyak. ${ }^{19}$

Industri perbankan telah mengalami perubahan besar dalam beberapa tahun terakhir. Industri ini menjadi lebih kompetitif karena deregulasi peraturan. Saat ini, bank memiliki fleksibilitas pada layanan yang mereka tawarkan, lokasi tempat beroperasi, dan tarif untuk simpanan deposan. ${ }^{20}$

Menyoal penguatan destinasi bank dan lembaga keuangan, perlu membahas makna destinasi terlebih dahulu. Destinasi menurut kamus

\footnotetext{
16 Andri Soemitra, Bank \& Lembaga Keuangan Syariah, (Jakarta: Kencana Prenada Media Group, 2009) hlm. 79-87

${ }^{17}$ Kasmir, Bank dan Lembaga Keuangan Lainnya, (Jakarta: Rajawali Press, 2014), Hlm. 3

${ }^{18}$ Ibid, hlm. 6

${ }^{19}$ Undang undang perbankan no 10 tahun 1998

${ }^{20}$ Thamrin Abdullah, Modul Lembaga Keuangan 1, (Yogyakarta: TP, 2012), hlm.3
} 
besar bahasa Indonesia adalah tempat tujuan pengiriman. ${ }^{21}$ Istilah destinasi biasa digunakan dalam kajian pariwisata. Kali ini istilah ini digunakan untuk membahas bank dan lembaga keuangan.

Berbagai inisiatif kebijakan sedang ditempuh oleh pemerintah untuk mendorong pengembangan sektor pariwisata, terutama di destinasi wisata prioritas. Rapat Koordinasi menyepakati 9 (sembilan) strategi kebijakan yang menjadi prioritas bersama Pemerintah Pusat, Pemerintah Daerah, Bank Indonesia, dan Otoritas Jasa Keuangan ${ }^{22}$. Dari Sembilan kebijakan strategis dan 1 monev penguatan destinasi wisata dapat diadopsi sebagai penguatan destinasi lembaga keuangan yaitu:

1. Penetapan strategi pencapaian kinerja bank dan LKNB melalui peningkatan aksesibilitas, keragaman produk, kualitas amenitas, didukung oleh penguatan promosi, dan peningkatan kapasitas pelaku industry keuangan.

2. Penguatan data dan informasi

3. Peningkatan akses permodalan melalui berbagai inovasi produk.

4. Penguatan sinergi promosi destinasi bank dan lembaga keuangan antara pemerintah, BI, OJK, bank dan LKNB, dengan masyarakat.

5. Penguatan akses/konektivitas

6. Peningkatan mutu dan kualitas layanan baik layanan yang berkaitan langsung dengan produk atau tidak.

7. Peningkatan kualitas SDM melalui pendidikan vokasi dan pelatihan.

8. Pemerintah, Bank Indonesia, dan Otoritas Jasa Keuangan akan melakukan monitoring dan evaluasi secara periodik terhadap pelaksanaan strategi kebijakan.

Selain delapan konsep di atas untuk memperkuat lembaga keuangan bank dan non bank sebagai destinasi transaksi keuangan, modal sosial dapat dikembangkan. Modal social dapat berbentuk kepercayaan, norma sosial tentang resiprositas, kerjasama, dan partisipasi dalam hubungan hubungan social, bukan individual. ${ }^{23}$

Berikut ini adalah daftar jaringan lembaga keuangan bank dan non bank yang berada di wilayah Kabupaten Banyumas per Juli $2018^{24}$ :

1. BPR $: 9$

${ }^{21}$ www.kbbi.wb.id, diakses 10 November 2018

${ }^{22}$ www.bi.go.id, diakses 30 Agustus 2018

${ }_{23}$ Sindung Haryanto, Sosiologi Ekonomi, (Yogyakarta: Ar Ruzz Media, 2016), hlm.171

${ }^{24}$ Dokumen OJK Purwokerto tentang Bank dan Lembaga Keuangan Non Bank, diakses 23 Agustus 2018 
2. BPRS

3. Bank umum

4. Bank Umum Syariah

5. Unit Usaha Syariah / KCS

6. Jaringan Kantor Perusahaan Asuransi jiwa

7. Jaringan Kantor Perusahaan Asuransi jiwa Syariah

8. BPJS Kesehatan dan ketenagakerjaan

9. Asuransi umum dan umum Syariah

10. Asuransi wajib

11. Jaringan Kantor Perusahaan Pergadaian

12. Jaringan Kantor Perusahaan Penjaminan
$: 3$

$: 26$

$: 5$

$: 2$

$: 19$

\section{Rentenir}

Rentenir atau sering juga disebut tengkulak adalah orang yang memberi pinjaman uang tidak resmi atau resmi dengan bunga tinggi. Pinjaman ini tidak diberikan melalui badan resmi, misalnya bank, dan bila tidak dibayar akan dipermalukan atau dipukuli. ${ }^{25}$ Dalam jurnal sosial dijelaskan bahwa rentenir secara bahasa berasal dari kata Rente yang artinya renten, bunga uang. Kata ini tidak jauh berbeda dengan makna Riba yang secara bahasa berarti Ziyadah (tambahan) baik dalam transaksi jual beli maupun pinjam meminjam. ${ }^{26}$

Ada beberapa hal yang membedakan antara rentenir dan lembaga keuangan yaitu ${ }^{27}$ :

\begin{tabular}{|l|l|l|}
\hline Indikator & Rentenir & Lembaga Keuangan \\
\hline Bunga & $20 \%$ / bulan & $2 \%$ / bulan \\
\hline Agunan & Tanpa agunan & Dengan agunan \\
\hline $\begin{array}{l}\text { Proses dan } \\
\text { administrasi }\end{array}$ & $\begin{array}{l}\text { Mudah, cepat, syarat } \\
\text { administrasi mudah }\end{array}$ & $\begin{array}{l}\text { Syarat administrasi } \\
\text { banyak, prose lama }\end{array}$ \\
\hline Eksekusi & $\begin{array}{l}\text { Eksekusi barang berharga } \\
\text { apapun bentuknya tanpa proses } \\
\text { lelang }\end{array}$ & $\begin{array}{l}\text { Ada proses lelang dan } \\
\text { tahapan yang jelas }\end{array}$ \\
\hline
\end{tabular}

${ }^{25}$ Monang Siahaan, Rentenir Penolong Pedagang Kecil, ( Jakarta: Elex Media Komputindo, ), hlm. 15

26 Ilas korwadi siboro, Rentenir (Analisis Terhadap Fungsi Pinjaman Berbunga Dalam Masyarakat Rokan Hilir Kecamatan Bagan Sinembah Desa Bagan Batu ) (Jom fisip vol. 2 no. oktober 2015), hlm.1

${ }^{27}$ Monang Siahaan, Rentenir..., hlm. 20 
Penelitian tentang rentenir yang telah dilakukan oleh $\mathrm{Yesi}^{28}$ dapat disimpulkan bahwa:

1. Profesi rentenir dijalankan oleh orang yang pada umumnya telah memiliki pengetahuan, pengalaman serta telah berkecimpung dalam pasar perkreditan.

2. Nasabah rentenir terdiri dari:

a. Orang-orang dengan tingkat perekonomian rendah yang membutuhkan kredit untuk kebutuhan hidup sehari-hari maupun untuk berusaha.

b. Orang-orang dengan tingkat perekonomian menengah untuk memenuhi terutama kebutuhan ekonomi sekunder dan tresier.

3. Beberapa motivasi rentenir menjalankan bisnis hutang-piutang uang yaitu: keuntungan yang besar dari bisnis ini, variasi dari pekerjaan, warisan bisnis keluarga, lingkungan sosial yang kondusif

Ada tiga bentuk hubungan sosial antara tentenir dan masyarakat (debitur) yang dapat disimpulkan dari penelitian Yoserizal yaitu ${ }^{29}$ : hubungan kepercayaan, hubungan saling ketergantungan, dan hubungan eksploitasi

\section{E. Preferensi Pedagang Pasar Wage}

Sebelum menjelaskan preferensi pedagang terlebih dahulu dijelaskan tentang gambaran umum pasar wage. Pasar Wage purwokerto (pasar tradisional) dibangun kira-kira pada abad ke-19 di jaman penjajahan belanda ayang bertujuan untuk memperlancar aktifitas perekonomian dan pemasaran belanda. Pada saat masih di jalan jendral soedirman, Pasar Wage lama berdekatan dengan kedemangan yang saat ini dibangun sebuah klenteng di utara pasar. Di Pasar Wage lama terdapat kurang lebih 1200 los dan 61 kios dengan kapasitas 1600 pedagang.

Nama "WAGE" dijadikan sebagai nama pasar karena pada saat wage (hari pasaran), pasar lebih ramai dikunjungi pembeli daripada hari biasa. Namun pada saat ini, hal tersebut tidak berpengaruh karena hampir setiap hari Pasar Wage ramai dikunjungi para pembeli. ${ }^{30}$

${ }^{28}$ Yoserizal dan Yesi, Hubungan Social Antar Rentenir Dan Nasabah. Suatu Studi Tentang Rentenir Dikecamatan Rumbai Kota Pekanbaru, Fakultas Ilmu Sosial Dan Ilmu Politik Jurusan Sosiologi Universitas Riau, repository.unri.ac.id, diakses 15 Agustus 2018

${ }^{29}$ Yoserizal dan Yesi, Hubungan Social Antar..., hlm. 11 diakses 15 Agustus 2018

${ }^{30}$ Dokumen Pengelola Pasar Wage, diakses pada 17 September 2018 
Pasar Wage yang letaknya di Kecamatan Purwokerto Timur dengan luas lahan sekitar $3.550 \mathrm{~m}^{2}$. Namun karena daya tampung pedagang tidak mencukupi dan tidak layak, Pemerintah Kabupaten Banyumas bekerja sama dengan pihak ketiga yaitu PT. Pumas Basata membangun Pasar Wage baru dengan menempati lahan seluas 10.305,44 $\mathrm{m}^{2}$.

Pasar Wage baru diresmikan pada tanggal 6 maret 2002. Pasar Wage terdiri dari beberapa blok: blok C (sayur-mayur dan buah-buahan), Blok A (pakaian, alat rumah tangga dan aneka logam), blok B (sembako, daging sapi, daging kambing, daging unggas dan ikan air tawar), blok D lantai 2 (berbagai jenis barang).

Meskipun sudah direnovasi namun kenyataannya tetap saja masih banyak pedagang yang berjualan di jalan-jalan dan tidak mau menaati peraturan yang telah ditetapkan oleh pemda. Misalnya dengan mengurangi luas tempat untuk pembeli satu meter agar pedagang dapat tertampung, memisahkan jenis dagangan yang kering di lantai dua dan yang basah di lantai satu. Tetapi pedagang berdalih bahwa peraturan itu dapat merugikan pedagang sehingga barang dagangannya tidak laku, hal ini dibuktikan dengan banyaknya kios-kios di lantai dua yang kosong serta tatanannya yang tidak terlalu tertib. ${ }^{31}$

Ada beberapa hambatan yang dihadapi oleh pengelola pasar wage dalam pengelolaan pasar yaitu ${ }^{32}$ :

a. Pedagang membayar bea tidak sesuai dengan tarif ;

b. Sepinya pengunjung pada lantai II berakibat banyak kios/Ios yang tutup karena bangkrut dan berjualan pada lahan parkir \& jalan;

c. Banyak pedagang lantai II yang berjualan dilokasi PKL, lokasi parkir dan di tempat larangan berjualan sehingga pungutan tidak maksimal;

d. Pungutan yang diperoleh dari pendapatan bea harian khususnya pada kios pasar belum sesuai dengan tari yang seharusnya ditetapkan, karena pedagang tidak mau membayar secara penuh karena alasan sepi pengunjung sehingga mengurangi target PAD;

e. Pada pengelolaan MCK banyak terjadi tunggakan pembayaran dan sulit untuk diupayakan sesuai dengan jumlah kontribusi yang seharusnya masuk;

${ }^{31}$ Pamulih dan Wijdanarko, Pemetaan Pengaruh Perkembangan Pasar Wage Kota Purwokerto Terhadap Lingkungan Permukiman

Sekitar,

http://ejournal.undip.ac.id/index.php/geoplanning, Volume 1, No 1, 2014, 33-43

32 Wawancara dengan Didik selaku pengelola Pasar Wage Purwokerto, pada 18 juli 2018

\section{el-JIZYA}


f. Pada lokasi Blok B bekas kebakaran dan Blok C masih belum sesuai pembayaran bea harian pasca kebakaran;

g. Pembuangan sampah lantai II ke TPS mengalami kesulitan, karena jalannya terlalu curam;

Permasalahan yang telah diidentifikasi oleh pengelola pasar adalah:

a. Pasca perpindahan banyak pedagang tidak puas terhadap kondisi pasar baru;

b. Belum ada sanksi yang tegas terhadap pedagang yang membayar retribusi tidak sesuai tarip dan terhadap pedagang yang melanggar berjualan pada tempat yang tidak diijinkan / larangan berjualan;

c. Banyak terjadi pengalihan hak dibawah tangan tanpa sepetahuan pihak pasar;

d. Jumlah alat ketertiban umum yang masih minim;

e. Parkir kendaraan tidak tertata rapi, terutama dalam jalan / lorongan pasar;

Dari data jumlah pedagang pasar wage Purwokerto sebesar 1777, yang aktif hanya 622. Hal ini menunjukkan bahwa lebih dari $50 \%$ pedagang tidak aktif berjualan.Tidak aktif yang dimaksud adalah berhenti berjualan atau berjualan tetapi kadang kadang (tidak rutin). ${ }^{33} \mathrm{Hal}$ ini dikarenakan beberapa alasan yaitu: barang yang dijual tidak laku; pedagang tidak bisa menciptakan inovasi dan differensiasi produk; terlalu banyak pesaing untuk barang yang sama; pembeli mulai sepi setelah adanya pasar modern (minimarket dan supermarket); beberapa pedagang pindah ke lokasi lain (di luar wilayah pasar wage); pedagang kehabisan modal, dikarenakan tidak bisa mengatur keuangan dan barang dagangan.

Dari keenam permasalahan di atas, peneliti membidik permasalahan permodalan. Permasalahan ini kerap dimanfaatkan oleh pihak ketiga (bisnis keuangan informa) masuk sebagai pahlawan bagi mereka. Berdasar penelitian dan kajian yang dilakukan oleh Bank Indonesia yang dihadiri oleh beberapa pimpinan bank teknis (BRI, BCA dan BPD), Kadin (Kamar dagang dan Industri), Akademis dari Unseod, Pelaku usaha di bidang keuangan informal. Hasil penelitian menunjukkan bahwa 22,73\% dari pedagang/bakul di pasar menggunakan modal pinjaman dari Bank Plecit untuk menopang usahanya. Dalam resume penelitian juga menunjukkan bahwa Bank plecit mengenakan tingkat bunga atas pinjaman sebesar 20$100 \%{ }^{34}$.

${ }^{33}$ Wawancara dengan Didik selaku Kepala TU Pasar Wage Purwokerto, pada 18 Juli 2018 ${ }^{34}$ www.bi.go.id, diakses pada 16 Juli 2018 
Dalam diskusi disampaikan bahwa diskusi informal ini diharapkan bisa menghasilkan beberapa hal, yaitu :

a. Terbangunnya jembatan komunikasi dengan para pelaku bisnis keuangan informal;

b. Terbangunnya persepsi masyarakat yang lebih baik, ,mendapat apresiasi yang layak dan tidak berseberangan dengan hukum-hukum yang berlaku dan;

c. Terbentuknya semangat awal untuk membentuk lembaga atau semacama perhimpunan pelaku bisnis di bidang keuangan informal sehingga mempermudah dalam berkomunikasi dan berkoordinasi.

BI berkepentingan dengan hal ini mengingat pasar, tempat beroperasionalnya bisnis ini, merupakan salah satu parameter ekonomi sebuah daerah. Sementara itu, dinamika pasar sangat dipengaruhi oleh faktor kemudahan akses permodalan bagi para pelaku bisnis di pasar tersebut.

Ada beberapa hal menarik dari penjelasan para pelaku bisnis infomal di sektor keuangan antara lain : (i) "regulasi perbankan" yang terkesan kaku dan birokratif, menjadi titik celah yang menginspirasi tumbuh dan berkembangnya laju pertumbuhan "bisnis keuangan informal" semacam ini dan; (ii) "mudah diakses, cepat, tidak birokratis serta bersifat kekeluargaan" menjadi ciri yang melekat dalam menjalankan bisnis keuangan informal. Tidak sedikit diantara pelaku bisnis informal yang bangkrut dan gulung tikar sebab gagal dalam me-maintenance nasabah sehingga kemacetan total tidak terhindarkan ${ }^{35}$.

Hal menarik lainnya adalah salah satu bank "pernah gagal" dalam menjalankan bisnis keuangan di lingkungan pasar walaupun sudah menawarkan jasa yang jauh lebih rendah apabila dibandingkan dengan para "bakul duit" (pelaku bisnis informal) ini. Rangkaian permasalahan di atas seperti mata rantai yang tidak terputus dan saling berkaitan. Masyarakat untuk memenuhi kebutuhan hidupnya bekerja sebagai pedagang. Jika tidak jeli dan baik dalam mengatur barang dagangan maka mereka akan mengalami masalah dengan kehabisan barang dagangan, secara otomatis akan terkendala dalam hal permodalan.

Modal tidak dengan mudah didapatkan karena terkait dengan banyak hal diantaranya sebagaimana disebutkan di atas: aturan yang rumit, jaminan (agunan) yang tidak dimiliki, proses lama dan sulit.karena banyak halyang dipertimbangkan dalam menentukan sumber permodalan, pada

${ }^{35}$ Wawancara dengan Arsyad Dalimunte, 16 Juli 2018 
akhirnya pedagang akan memilih sumber permodalan dengan pertimbangan banyak faktor.

Berikut ini akan dipaparkan data dan analisis prefernsi pedagang pasar wage dalam memilih sumber permodalan dengan jumlah sampel 100 pedagang yang diambil dengan snowball sampling:

Data Sumber Permodalan Pedagang Pasar Wage ${ }^{36}$

\begin{tabular}{|l|l|l|}
\hline No & Sumber Permodalan & Pedagang \\
\hline 1 & Saudara / teman / pribadi & $23 \%$ \\
\hline 2 & Bank konvensional & $35 \%$ \\
\hline 3 & Bank Syariah & $14 \%$ \\
\hline 4 & Lemaga keuangan lainnya & $17 \%$ \\
\hline 5 & Bank plecit / rentenir & $11 \%$ \\
\hline
\end{tabular}

Beberapa faktor yang menyebabkan mereka memilih (menentukan preferensi) sumber permodalan diantaranya adalah:

a. Sumber permodalan saudara / teman: proses mudah, tidak ada tambahan (bunga), tidak ada beban (terikat), dapat dipercaya, aman dan nyaman, mudah komunikasi, tidak banyak tuntutan, modal tidak harus berupa uang, pedagang bisa meminjam (mengambil) barang dari juragan / teman. Modal dikembalikan jika barang sudah laku terjual.

b. Sumber permodalan bank konvensional: Mudah, Keamanan terjamin, Bank milik pemerintah, Kenyamanan, Kualitas pelayanan, Fasilitas yang diberikan (outlet teras di pasar), Bunga rendah, Tetap diberikan kredit walaupun ada kredit macet di bank sebelumnya (bank pundi).

c. Bank syariah: Imbalannya rendah, Sistemnya sesuai dengan aturan syariah, Penjelasan transaksi secara detail (bagi hasil, margin, ujroh dijelaskan secara rinci pembagian/ angkanya).

d. Lembaga keuangan lainnya (non bank): Proses mudah, Persyaratan (administrasi) mudah, Bunga rendah, Tidak ada denda ketika telat membayar (pelanggan koperasi), Lingkungan (tetangga, teman, dan saudara), Mengenalnya koperasi karena sudah cukup lama.

e. Bank plecit / rentenir: Proses Mudah, Pencairan Cepat (tidak menunggu lama), Tidak ada syarat yang sulit, bahkan ada yang tanpa

${ }^{36}$ Observasi dan wawancara ke 50 pedagang pasar wage Purwokerto, Juli - Oktober 2018 
syarat apapun, Untuk pinjaman di bawah 10 juta sangat mudah, cepat, dan fleksibel.

Pada awal tahun 2017 masih cukup banyak pedagang yang menggunakan jasa rentenir. Namun mulai akhir tahun 2017 pedagang sudah mulai paham dan menyadari keterlibatan mereka dengan rentenir akan menyebabkan hal hal yang tidak diinginkan ${ }^{37}$. Ada peristiwa (kasus) yang terjadi antara pedagang dengan rentenir. Pedagang merasa bahwa hutangnya sudah lunas (modal + bunga), tetapi menurut catatan rentenir hutangnya masih cukup banyak. Karena kasus tersebut, para pedagang melakukan penyerangan kepada rentenir.

Dengan adanya kejadian itu jumlah rentenir (mayoritas pendatang dari Batak) sudah mulai berkurang. Hal ini karena ketakutan rentanir terhadap para pedagang dan kesadaran pedagang akan bahayanya terlibat dengan rentenir sudah mulai ada.

Dari data tabel sumber permodalan pedagang masih ada $11 \%$ yang menggunakan jasa rentenir. Mereka tetap menggunakan jasa rentenir walaupun sudah menyadari bahayanya karena tidak ada alternative lain yang dapat mereka akses. Dikarenakan sudah terlalu banyak terlilit hutang, tidak memenuhi syarat untuk mendapat modal dari sumber lain (hanya dari rentenir). Mayoritas mereka adalah pedagang yang sulit untuk diatur atau pekerja yang tidak memiliki akses ke lembaga permodalan lain. ${ }^{38}$

Tidak dapat dipungkiri bahwa ketika banyak orang meyakini bahaya rentenir, tetapi beberapa lainnya tetap mengidolakan rentenir sebagai alternative solusi sumber permodalan. Sebagaimana dijelaskan Arsyad bahwa fakta rentenir diidolakan masyarakat karena kecepatan eksekusi (tanpa syarat/ cukup KTP) dan tanpa agunan. ${ }^{39}$

\section{F. Upaya Perlindungan Pemerintah Terhadap Masyarakat Dari Rentenir}

Pemerintah dalam hal ini kementerian, OJK, dan Bank Indonesia telah melakukan berbagai upaya perlindungan terhadap msyarakat dari rentenir.

\footnotetext{
${ }^{37}$ Wawancara dengan Ibu Juri (pedagang buah), pada 15 Oktober 2018

${ }^{38}$ Wawancara dengan Ibu Sirun (Pedagang Ayam potong), pada 15 Oktober 2018

${ }^{39}$ Wawancara dengan Arsyad Dalimunte (Kepala Kadin Banyumas), pada 16 Juli 2018
} 
Upaya yang dilakukan tidak terbatas oleh waktu (periode) tetapi dilakukan selama bahaya rentenir masih Nampak di kalangan masyarakat.

Sebenarnya lembaga keuangan informal di sini tidak hanya rentenir (bank plecit), banyak keuangan informal lain yang mengatasnamakan lembaga resmi (paling banyak koperasi "abal abal"). Koperasi semacam ini (illegal) tidak jauh berbeda dari kinerja rentenir. Dalam prakteknya koperasi seharusnya dapat memberikan pembiayaan kepada anggotanya, permasalahan yang terjadi masyarakat (debitur) selalu menjadi calon anggota, tidak sebagai anggota.

Berikut akan dipaparkan perbedaan antara lembaga informal (koperasi "abal abal") dan koperasi. Koperasi memberikan 7 hak kepada anggotanya yang tidak dilakukan oleh koperasi abal abal yaitu pemilih, pemodal, pengguna, pemberian insentif (SHU), pengurus, pengawas, promotor (pengembangan potensi). Koperasi di dalamnya ada proses edukasi dan pelibatan anggota.

Koperasi keuangan merupakan elemen penting dan strategis dalam inklusi keuangan. International Cooperative Alliance mendapati model koperasi di sektor keuangan mikro lebih mampu menjangkau individu dan keluarga dibanding model lembaga keuangan lainnya. Ironisnya, banyak koperasi yang disalahgunakan sebagai kedok meraup keuntungan besar alias koperasi abal -abal dan melanggengkan praktik rentenir. Rentenir memang ada dalam ketiadaan (ketiadaan lembaga keuangan bank dan non bank / lembaga keuangan legal dan formal).

Perlu perhatian serius untuk melindungi masyarakat dari kejahatan finansial dengan pengawasan yang efektif untuk mengembalikan koperasi kepada jatidiri dan fungsinya sebagai alat inklusi, dan lebih penting lagi demokratisasi ekonomi.

Walaupun belum optimal tetapi pemerintah dalam hal ini telah melakukan berbagai upaya dalam melindungi masyarakat dari lembaga keuangan informal "abal abal". Diantara upaya yang dilakukan adalah"

a. Memberikan sosialisasi baik secara tatap muka atau menggunakan media cetak/elektronik dalam rangka melakukan tindakan prefentif

${ }^{40}$ Wawancara tertutup dengan Ibu Rosi (OJK), pada 23 Agustus 2018 
supaya masyarakat tidak menggunakan jasa rentenir apabila membutuhkan dana melainkan menggunakan produk jasa keuangan yang resmi yang pengawasanya di bawah OJK

b. Bentuk nyata upaya pemerintah OJK dalam memberantas rentenir yaitu dengan aktif mendorong lembaga jasa keuangan di bawah pengawasanya menciptakan produk dengan skim khusus sesuai dengan kebutuhan masyarakat, khusus masyarakat menengah ke bawah, antara lain:

1) Kredit Usaha Rakyat (Program Nasional)

2) Pembiayaan Ultra Mikro (UMi) (Program Nasional)

3) Pada Tahun 2017 OJK purwokerto telah menginisiasi produk skim kredit murah kepada BPR/BPRS yang berada di wilayah kerja OJK Purwokerto yatu layanan keuangan dalam rangka membrantas rwntenir (Laku Semar) di mana kredit tersebut memiliki spesifikasi sebagai berikut:

4) Kredit tanpa angunan, hanya dibutuhkan KTP saja.

5) Plafond kredit Rp 100.000 - Rp 3.000.000. besarnya pinjaman menyesuaikan jenis dagangan dan lokasi dagang

6) Suku bunga maksimal $2 \%$ /bulan dan biaya administrasi $1 \%$.

7) Dapat tidak memakai angunan tambahan dan wajib memiliki usaha (di pasar).

8) Jangka waktu maksimal 2 tahun.

9) Analisa kredit dan perjanjian kredit/akad dibuat khusus dan lebih sederhana.

10) Angsuran bulanan yang tercantum dalam akad/perjanjian namun penghimpunan/penarikan angsuran dapat dilakukan harian atau mingguan. Angsuran dapat mingguan jika perangkat system informasi perbangkan dapat mengkomodir.

11) Pencairan pinjaman dpat dilakukan di tempat usaha debitur setelah dilakukan proses perencanaan/pemdataan dan analisis pada hari sebelumnya.

12) Jam kerja dimungkinkan menggunakan system shift menyesuaikan waktu operasional pasar. 
13) Pelayanan perbangkat untuk skema khusus dapat dilakukan di luar hari jam kerja.

14) Media promosi skema kredit khusus dapat menggunakan brosur yang dilengkapi dengan simulasi pembayaran (harian, mingguan, bulanan) dan disampaikan ke masing-masing pedagang.

15) Selain dapat pinjaman, debitur juga dapat ditawarkan untuk menabung.

OJK Purwokerto telah menginisiasi produk skim kredit murah kepada BPR/BPRS yang berada di wilayah kerja OJK Purwokerto yaitu laku semar dimana kredit tersebut memiliki bunga yang murah yaitu maksimal 2\%/bulan. Perlu difahami, untuk memberantas rentenir adalah hal yang sulit. Namun, OJK berharap dengan membuat produk yang murah dan mudah dijangkau oleh masyarakat, masyarakat akan beralih kepada produk keuangan resmi. Dengan beralihnya masyarakat kepada produk keuangan yang resmi, OJK berharap para rentenir akan hilang satu demi satu atau rentenir akan menurunkan suku bunganya seingga tidak menjerat masyarakat.

Berdasarkan hasil wawancara hingga periode juli 2018, kantor Otoritas jasa keuangan OJK Purwokerto belum mendapat laporan pengaduan konsumen terkait rentenir. Hal ini menunjukkan bahwa upaya yang dilakukan pemerintah sudah baik tetapi belum dimanfaatkan oleh masyarakat. Terbukti dengan adanya masalah yang dihadapi oleh pedagang pasar wage kaitannya dengan rentenir, tetapi mereka tidak mengadukan (melaporkannya) kepada pemerintah (OJK). Di bawah ini beberapa dokumentasi hasil observasi peneliti untuk menunjukan berbagai upaya yang dilakukan OJK: ${ }^{41}$ Majalah edukasi konsumen (majalah ini diterbitkan dalam dua versi yaitu versi cetak dan versi online yang dapat diunduh pada sikapiuangmu.ojk.go.id; pamflet; standing banner.

Dalam kajian akademisi dan praktisi yang dilakukan di Hall Perpustakaan IAIN Purwokerto, ada upaya yang bisa dilakukan dalam

${ }^{41}$ Dokumen OJK diakses pada 20 Agustus 2018 
mengatasi rentenir/ investasi bodong/ investasi abal abal yaitu menggunakan Quadro Helix Model of Cooperative Governance ${ }^{42}$.

Quadro helix merupakan model sinergi yang dikembangkan dalam teori inovasi untuk mendorong daya saing dan pertumbuhan ekonomi suatu daerah/negara. Dalam model QH Terdapat empat aktor utama yang diharapkan dapat menggerakkan lahirnya kreativitas, ide, ilmu pengetahuan dan teknologi dalam pembangunan ekonomi. Keempat aktor tersebut, yaitu komunitas, intelektual, bisnis dan pemerintah. Model ini dapat diadopsi sebagai model sinergi multipihak dalam pengawasan koperasi keuangan untuk mengatasi keterbatasan sumber daya pengawasan dari pemerintah.

Dalam reformasi keuangan yang demokratis, masyarakat harus hadir dalam isu-isu kebijakan pelayanan keuangan, implementasi dan pengawasannya. Partisipasi publik muncul dalam bentuk kesadaran, keterlibatan dan promosi praktik layanan keuangan yang baik dan juga pengawasannya. Inisiatif-inisiatif komunitas dalam bentuk pengaduan, investigasi hingga advokasi korban koperasi abal-abal merupakan bentuk partisipasi aktif publik yang perlu dikomunikasikan dan disinergikan dengan kebijakan pengawasan koperasi.

${ }^{42}$ Materi diskusi koperasi disampaikan oleh Dani Kusumastuti (Dosen FEBI IAIN Purwokerto), pada 13 Maret 2018 


\section{Daftar Pustaka}

Afzalur Rahman, 1995, Doktrin Ekonomi Islam, Yogyakarta: Dana Bhakti Wakaf.

Andi Mappiare, 1994, Psikologi Orang Dewasa Bagi Penyesuaian Dan Pendidikan, Surabaya: Usana Offsetprinting.

Andri Soemitra, 2009, Bank \& Lembaga Keuangan Syariah, Jakarta:

Kencana Prenada Media Group.

Dani Kusumastuti, 2018, Materi diskusi koperasi (IAIN Purwokerto: TP).

Ilas korwadi siboro, 2015, Rentenir (Analisis Terhadap Fungsi Pinjaman

Berbunga Dalam Masyarakat Rokan Hilir Kecamatan Bagan Sinembah

Desa Bagan Batu ) (Jom fisip vol. 2 no. oktober 2015.

Kasmir, 2011, Kewirausahaan, Edisi Revisi, Jakarta: Rajagrafindo

Persada.

, 2013, Kewirausahaan, Jakarta: Rajawali Pers. ,2014, Bank dan Lembaga Keuangan Lainnya, Jakarta: Rajawali Press.

Mar'atus Syawalia Navis, 2015, Preferensi Pedagang Pasar Tradisional terhadap Sumber Permodalan, Jurnal Ekonomi Dan Bisnis, Malang; Universitas Brawijaya.

Monang Siahaan, Rentenir Penolong Pedagang Kecil, Jakarta: Elex Media Komputindo.

Nugroho, J. Setiadi, 2013, Perilaku Konsumen, Jakarta: Kencana Prenada Meida Group.

Nur Rianto Al Arif, 2014, Teori Mikroekonomi, Jakarta: Kencana.

Pamulih dan Wijdanarko, Pemetaan Pengaruh Perkembangan Pasar Wage Kota Purwokerto Terhadap Lingkungan Permukiman Sekitar, http://ejournal.undip.ac.id/index.php/geoplanning, Volume 1, No 1, 2014.

Philip Kotler, 2000, Manajemen Pemasaran, Jakarta: Prehalindo.

Rustam Efendi, 2003, Produksi Dalam Islam, Yogyakarta: Magister Press

Bekerjasama dengan MSI UII, 
Sindung Haryanto, 2016, Sosiologi Ekonomi, Yogyakarta: Ar Ruzz Media.

Thamrin Abdullah, 2012, Modul Lembaga Keuangan 1, Yogyakarta: TP. Toti Indrawati dan Indri Yovita, 2014, Analisis Sumber Modal Pedagang

Pasar Tradisional di Kota Pekanbaru, Jurnal Ekonomi, Vol. XXII, Pekanbaru; Universitas Riau.

Undang undang perbankan no 10 tahun 1998.

www.bi.go.id

www.kbbi.wb.id

Yoserizal dan Yesi, Hubungan Social Antar Rentenir Dan Nasabah. Suatu

Studi Tentang Rentenir Dikecamatan Rumbai Kota Pekanbaru, Fakultas Ilmu Sosial Dan Ilmu Politik Jurusan Sosiologi Universitas Riau, repository.unri.ac.id. 